\title{
Neophobia and Learning Mechanisms: How Captive Orangutans Discover Medicinal Plants
}

\author{
Erik Gustafsson ${ }^{\mathrm{a}, \mathrm{b}}$ Sabrina Krief ${ }^{\mathrm{b}}$ Michel Saint Jalme ${ }^{\mathrm{a}}$ \\ a UMR 7204 CERSP et ${ }^{b}$ UMR 7206 Éco-Anthropologie et Ethnobiologie, Muséum National \\ d'Histoire Naturelle, Paris, France
}

\section{Key Words}

Weaned orangutans $\cdot$ Neophobia $\cdot$ Social influence $\cdot$ Zoopharmacognosy $\cdot$ Plant selection

\begin{abstract}
Great apes sometimes feed on items of low nutritional value with bioactive secondary compounds. These molecules may be toxic and neophobia is presumed to be an essential factor in avoiding the ingestion of noxious items. The aim of this study is to investigate, in captive orangutans, individual and social learning involved in the discovery and ingestion of new items. We presented novel aromatic plants - 11 fresh plants and 4 infused plants - to 4 captive weaned Bornean orangutans, both under isolated and group conditions, and recorded their behaviour and interactions between group members. All animals tasted by nibbling or ingested most of the plants presented. Regardless of the experimental condition, individual responses did not vary visibly across the sessions, despite numerous close observations, and food transfers between individuals were observed. Our results suggest that a low level of neophobia and a strong propensity to look to conspecifics for information allow Bornean orangutans to expand their diet after weaning. Our results also provide some evidence that olfaction is a key sense in determining food edibility based on previous experience.
\end{abstract}

Copyright $\odot 2011$ S. Karger AG, Basel

\section{Introduction}

Self-medication in great apes was hypothesized after the observation of roughleaf swallowing by chimpanzees [Wrangham and Nishida, 1983; Wrangham, 1995; Huffman et al., 1996; Huffman and Caton, 2001]. Since then, the identification of several secondary compounds with pharmacological properties in plants consumed

\begin{tabular}{ll}
\hline KARGER & ( ) 2011 S. Karger AG, Basel \\
Fon +41613061234 & \\
$\begin{array}{l}\text { E-Mail karger@karger.ch } \\
\text { www.karger.com }\end{array}$ & $\begin{array}{l}\text { Accessible online at: } \\
\text { www.karger.com/fpr }\end{array}$
\end{tabular}

Erik Gustafsson

Muséum National d'Histoire Naturelle

Ménagerie du Jardin des Plantes, 57 rue Cuvier

FR-75005 Paris (France)

Tel. +33 1407957 30, E-Mail gustafsson@mnhn.fr 
by chimpanzees has reinforced this hypothesis [Huffman and Seifu, 1989; Huffman, 1997; Krief et al., 2004, 2005, 2006]. Self-medication by fur-rubbing behaviour has also been hypothesized in orangutans [Morrogh-Bernard, 2008]. In addition, this species is known to have a highly diversified diet including items of low nutritional value that may contain secondary compounds [Leighton, 1993; Knott, 1998].

Although such molecules can be curative, they can also be highly toxic [Ames et al., 1990; Blackwell, 1990]. Primates perceive bitter or astringent tastes, which prevent them from consuming large amounts of plants, thereby avoiding intoxication [Freeland and Janzen, 1974; Glander, 1982; Hladik and Simmen, 1998; Steiner et al., 2001]. However, orangutans are known to show a low sensitivity to tannins among primates [Simmen and Charlot, 2003]. Therefore, another efficient behavioural strategy for avoiding toxic substances is food neophobia, defined as the reluctance to eat novel foods [Barnett, 1958].

Individual learning by trial and error associated with instantaneous and postingestive feedback appears to be a reliable approach to discover novel edible foods [Milton, 1993; Laska et al., 2000; Laska, 2001; Visalberghi et al., 2003]. Social learning - defined by Heyes [1994] as learning that is influenced by observation of, or interaction with, another animal (typically a conspecific) or its products - can also influence such behaviour in primates [Visalberghi and Fragaszy, 1995; Vitale and Queyras, 1997; Visalberghi and Addessi, 2000, 2001; Addessi and Visalberghi, 2001; Huffman and Hirata, 2004]. In the semi-solitary Bornean orangutans [Galdikas, 1985], social interactions of infants are limited to their mother, and social learning is only known to occur before weaning [Jaeggi et al., 2008, 2010]. In the wild, orangutans have to cope with wide fluctuations of food availability [Knott, 1998]. After weaning, according to Greenberg [1990], animals in unstable habitats should exhibit flexible feeding behaviours via low neophobia. Thus, food choice may rely more on plant criteria than on reference to models. Therefore, besides the unpleasant tastes often associated with toxic secondary compounds, anteoral evaluation, being tactile, visual and olfactory, could significantly influence the intake of unfamiliar items in orangutans, as has been observed in other primates [Dominy et al., 2001; Dominy, 2004; Rolls, 2005; Laska et al., 2007].

To investigate whether and how orangutans discover and accept potentially medicinal plants with a low nutritional value after weaning, we presented fresh novel plants to 4 captive weaned Bornean orangutans, both individually in isolation and in their group. In addition, to understand better the key senses used in novel item evaluation, we limited the sensory cues related to texture, colour and odour by using one of the most common preparations in traditional herbal medicine: infusion (i.e. the extraction of chemical compounds by pouring boiling water on leaves and letting them steep for a few minutes). In this study, we tested the following predictions: (1) because orangutans need to sample many items to be able to survive in an unstable environment, they would not display a strong phobia of novel items; (2) since they are semisolitary, social facilitation in orangutans after weaning would be very minimal, and (3) to gain novel information, orangutans would show interest in fresh plant scents and texture and would taste all infusions because of the limited sensory cues available. 


\section{Methods}

\section{Study Site and Subjects}

This study involved 4 Bornean orangutans (Pongo pygmaeus) housed at the Ménagerie du Jardin des Plantes, a zoo belonging to the National Museum of Natural History in Paris. For all animals, we had complete information about their history since birth, the composition of their diet and their health status. The group was composed of Nénette, Wattana and Tübo. Dayu was housed separately from them but in full view of the group during the period of the experiments, except when he was being tested under the individual condition. Nénette (37 years old), wild born, arrived at the Ménagerie when she was 3 years old. She is the mother of two males, Tübo (13 years old) and Dayu (7 years old), whom she reared. Wattana (11 years old) was reared by humans at the Stuttgart Wilhelma Zoological and Botanic Garden nursery and was transferred to the Ménagerie when she was 30 months old. The group was housed in two indoor cages (total size: $2.5 \times 7 \times 4.5 \mathrm{~m}$ ). Under the individual condition, the primates were isolated with no possible eye contact. All orangutans were given turns accessing an outdoor enclosure $(13 \times 6.5 \times$ $4.5 \mathrm{~m}$ ). They were fed at 9.00 a.m., 2.30 p.m. and 5.30 p.m. with varied fruits, vegetables and primate pellets. They also received 1 yogurt per day.

The health status (any symptoms of cold, fatigue, diarrhoea) of the animals was monitored during the experiment. The orangutans were treated regularly for internal parasites, and the last treatment was given 2 months before the beginning of this study. Before the end of the study, Nénette underwent surgery, and therefore did not participate in all of the sessions.

\section{Procedure}

From February to May 2007, we conducted a series of sessions during which we presented the animals with 15 different plant species (table 1). Seven fresh plants were presented 2-5 times to isolated animals (individual condition). Four fresh plants were presented 5 times to the group (group condition). Finally, 4 infused plants were presented twice under the individual condition (table 1). All plants used in the experiments came from the Museum's botanical garden and were chosen according to the following criteria: (1) novelty (not known by the orangutans studied); (2) belonging to the French pharmacopoeia (i.e. included in the list of legal therapeutic plants published by the French health authority); (3) no known toxicity to primates; (4) availability for the duration of the experiments, and (5) organically grown to avoid possible selection biases of the orangutans due to the taste or smell of pesticides. Presentation sessions for the same plant were conducted 2 or 3 days apart depending on possibilities for isolating individuals and plant availability. Each day of experiment, 2 plants were presented in turn for $30 \mathrm{~min}$ each, with a minimum of 15 min between each presentation to avoid loss of interest and mixing tastes. The sessions took place in the morning between 10.00 and $12.00 \mathrm{~h}$, or in the afternoon between 15.30 and $16.30 \mathrm{~h}$, about $1 \mathrm{~h}$ after each feeding time.

Presentation of Fresh Plants

For both individual and group conditions, stems were distributed from the top of the cage through a trapdoor, about 10 min after having been picked in the garden. One 10 -cm-long stem section per animal was distributed for each session. In order to provide an equivalent quantity of plant material, regardless of species, we chose sections bearing 10-50 leaves; the number depending on leaf size. The amount provided was determined in order to avoid satiation, but monopolization remained possible in the group.

Presentation of Plant Infusions

Infusions of 4 plants (marjoram, thyme, savory and pellitory-of-the-wall) were prepared. $100 \mathrm{mg}$ of dried and crushed leaves were steeped in $500 \mathrm{ml}$ of boiling water. 'Weak' and 'strong' infusions were prepared from each plant (leaves steeped for 3-5 and 15-20 min, respectively). Water, weak and strong infusions of the same plant at the same temperature $\left(38^{\circ} \mathrm{C}\right)$ were twice presented simultaneously in 3 graduated bottles of $500 \mathrm{ml}$ under the individual condition. The orangutans had access to the infusions and water using a fixed drinking straw for each bottle. Before beginning this study, they were trained to drink familiar beverages using this device. 
Table 1. Number of sessions per orangutan studied for each experimental condition, and for fresh and infused plants

\begin{tabular}{|c|c|c|c|c|c|c|c|}
\hline & \multicolumn{2}{|c|}{ Nénette } & \multicolumn{2}{|c|}{ Tübo } & \multicolumn{2}{|c|}{ Wattana } & Dayu \\
\hline & Ind & Gp & Ind & $\mathrm{Gp}$ & Ind & Gp & Ind $\mathrm{Gp}$ \\
\hline \multicolumn{8}{|l|}{ Fresh plants } \\
\hline Olive wood (Olea europaea) & 2 & & 2 & & 2 & & 2 \\
\hline Laurel (Laurus nobilis) & 2 & & 2 & & 2 & & 2 \\
\hline Bear's garlic (Allium ursinum) & & & 5 & & 5 & & 5 \\
\hline White deadnettle (Lamium album) & & & 5 & & 5 & & 5 \\
\hline Garlic mustard (Sisymbrium alliaria) & & & 5 & & 5 & & 5 \\
\hline Black horehound (Ballota nigra) & & & 5 & & 5 & & 5 \\
\hline Rocket (Eruca sativa) & & & 5 & & 5 & & 5 \\
\hline Sage (Salvia officinalis) & & 5 & & 5 & & 5 & \\
\hline Ground ivy (Glechoma hederacea) & & 5 & & 5 & & 5 & \\
\hline Balsam herb (Balsamita suaveolens) & & 5 & & 5 & & 5 & \\
\hline Hyssop (Hyssopus officinalis) & & 5 & & 5 & & 5 & \\
\hline \multicolumn{8}{|l|}{ Infused plants } \\
\hline Marjoram (Origanum majorana) & 2 & & 2 & & 2 & & 2 \\
\hline Thyme (Thymus vulgaris) & 2 & & 2 & & 2 & & 2 \\
\hline Savory (Satureja hortensis) & & & 2 & & 2 & & 2 \\
\hline Pellitory-of-the-wall (Parietaria officinalis) & & & 2 & & 2 & & 2 \\
\hline
\end{tabular}

\section{Data Collection}

All experiments were recorded with a video camera and represent $82.5 \mathrm{~h}$ of observation. For the fresh plants, we recorded the occurrences of holding (i.e. taking with hand or mouth), sniffing behaviours (i.e. plant in contact with nose) and potential consumption of plants, which we classified into 2 categories: (1) taste (i.e. licked, nibbled or at least held to mouth), and (2) ingestion (i.e. a significant mouthful of the plant eaten). For the infusions, we recorded the quantity ingested by each individual. We considered a solution to be 'tasted' when the individual consumed less than $100 \mathrm{ml}$ of liquid. We considered the infusion to be 'ingested' when more than $100 \mathrm{ml}$ was consumed.

Using a behaviour-dependent onset-of-sampling method [Altmann, 1974], we recorded plant-related interactions in the group:

(1) close observation, defined here as gazing at an item's possessor with less than $50 \mathrm{~cm}$ between both heads;

(2) begging, defined as extending an arm or lips towards an item's possessor;

(3) food sharing, defined as the transfer of a defendable food item from one food-motivated individual to another [Feistner and McGrew, 1989]; we distinguished 2 kinds of transfer - donation (i.e. possessor offers plants to its conspecifics after begging or not) and stealing (i.e. individual approaches the possessor and takes the item from its mouth, foot or hand).

For each transfer, we recorded if sharing involved palatable (i.e. leaves) or unpalatable plant parts (i.e. stems, petioles and wedges). Finally, for each plant-related interaction, we recorded the identities of the orangutans initiating (i.e. observer, giver without previous close observation by the receiver, beggar or robber) and solicited. 
Data Analysis

In order to compare the ingestion frequencies of fresh plants between the first session and the 4 successive sessions, we combined the data from the 4 sessions and took into account only the 9 plants that were presented on all 5 occasions. We analysed separately: (1) the frequency of ingestion of plants which were not ingested at the first presentation, and (2) the variation in frequency of ingestion of plants that were ingested at the first presentation. The differentiation of individual and group presentations results in 4 contingency tables of 2 lines $\times 2$ columns. We then used the Fisher exact probability test to measure the significance of the distribution frequencies. Fisher's exact test was also used to analyse differences in palatability between plant parts donated and those stolen. Because of the small sample size and dependency of sessions, we used a sign test to compare the proportion of orangutans ingesting infused plants between the first and second sessions.

For infusions, we used the Kruskal-Wallis test to compare quantities of water and weak and strong infusions ingested for each session. Finally, to evaluate interindividual differences in the degree of neophobia, we used the $\chi^{2}$ test to compare consumption frequency between individuals at the first presentation.

\section{Results}

\section{Presentation of Fresh Plants}

First Presentation

Under the individual condition, in all but 2 cases, the orangutans showed interest in the plants by holding them (table 2). Four out of the 7 plants presented were tasted or ingested by all individuals (p1: olive wood; p3: bear's garlic; p4: white deadnettle; p5: garlic mustard) and 2 others (p6: black horehound; p7: rocket) by at least 1 individual. Only 1 plant (p2: laurel) was neither tasted nor ingested by any animal. Three out of the 7 plants were sniffed at: laurel (p2), white deadnettle (p4) and black horehound (p6).

Under the group condition, all 4 of the plants presented were held by at least 2 of the 3 individuals. Three of these plants were also tasted or ingested by at least 2 individuals. One plant (p9: ground ivy) was neither tasted nor ingested by any animal. Two of the 4 plants were sniffed at by the orangutans.

\section{Comparison between First Presentation and Successive Sessions}

Plants which were not ingested during the first presentation (5 cases out of 15 presentations under the individual condition, and 7 cases out of 12 presentations under the group condition) (table 2) were also avoided during the successive sessions. Indeed, for these plants, no consumption was observed during the successive sessions in 14 cases out of 20 presentations under the individual condition (Fisher's exact test: $\mathrm{p}=0.289$ ) and in 27 cases out of 28 presentations under the group condition (Fisher's exact test: $\mathrm{p}=1.000$ ).

Plants which were ingested at the first presentation continued to be ingested during the successive sessions. The consumption frequencies for plants ingested at the first presentation did not differ significantly between first and successive sessions either under the individual condition $[100 \%(n=10) / 87.5 \%(n=40)$; Fisher's exact test: $\mathrm{p}=0.568]$ or under the group condition $[100 \%(n=5) / 60 \%(n=20)$; Fisher's exact test: $\mathrm{p}=0.140]$.

Regardless of the experimental condition, plants which were ingested by none or by only 1 individual at the first session (laurel and black horehound for the indi- 
Table 2. Occurrence of investigative behaviours (hold, sniff, taste or ingest) towards fresh plants for each experimental condition during first and second sessions for $\mathrm{p} 1$ and $\mathrm{p} 2$, and first and 4 successive sessions for other plants

\begin{tabular}{|c|c|c|c|c|c|c|c|c|c|c|}
\hline \multirow[t]{2}{*}{ Condition } & \multirow[t]{2}{*}{ Subjects } & \multirow[t]{2}{*}{ Plant } & \multicolumn{4}{|c|}{ First session } & \multicolumn{4}{|c|}{ Second session } \\
\hline & & & hold & sniff & taste & ingest & hold & sniff & taste & ingest \\
\hline \multirow[t]{4}{*}{ Ind } & 4 orangutans & p1 & 4 & 0 & 2 & 2 & 3 & 0 & 1 & 2 \\
\hline & & $\mathrm{p} 2$ & 4 & 4 & 0 & 0 & 3 & 3 & 2 & 0 \\
\hline & & & \multicolumn{4}{|c|}{ First session } & \multicolumn{4}{|c|}{4 successive sessions } \\
\hline & & & hold & sniff & taste & ingest & hold & sniff & taste & ingest \\
\hline \multirow[t]{5}{*}{ Ind } & 3 orangutans & p3 & 3 & 0 & 0 & 3 & 12 & 0 & 0 & 12 \\
\hline & & $\mathrm{p} 4$ & 3 & 2 & 1 & 2 & 12 & 5 & 2 & 9 \\
\hline & & p5 & 3 & 0 & 1 & 2 & 11 & 0 & 1 & 10 \\
\hline & & p6 & 2 & 1 & 0 & 1 & 10 & 4 & 6 & 0 \\
\hline & & p7 & 2 & 0 & 0 & 2 & 11 & 0 & 1 & 10 \\
\hline \multirow[t]{4}{*}{ Gp } & 3 orangutans & p8 & 2 & 1 & 1 & 1 & 8 & 6 & 1 & 3 \\
\hline & & p9 & 3 & 2 & 0 & 0 & 11 & 8 & 4 & 0 \\
\hline & & p10 & 3 & 0 & 1 & 2 & 10 & 0 & 2 & 6 \\
\hline & & p11 & 2 & 0 & 0 & 2 & 8 & 0 & 0 & 4 \\
\hline
\end{tabular}

p1 = Olive wood; $\mathrm{p} 2$ = laurel; $\mathrm{p} 3$ = bear's garlic; $\mathrm{p} 4$ = white deadnettle; $\mathrm{p} 5$ = garlic mustard; $\mathrm{p} 6$ = black horehound; 7 = rocket; $\mathrm{p} 8$ = sage; $\mathrm{p} 9=$ ground ivy; $\mathrm{p} 10=$ balsam herb; 11 = hyssop; Ind = individual condition; $\mathrm{Gp}=$ group condition.

vidual condition, and sage and ground ivy for the group condition) were not ingested during the 4 successive sessions (table 2). Finally, the 5 plants sniffed at during the first session were sniffed at during all other sessions. Moreover, 3 of the plants sniffed at were the ones that were not ingested by orangutans during the successive sessions (table 2).

\section{Interactions}

Forty-nine close observations and 34 instances of food sharing were observed in the group. Wattana initiated $55 \%$ of all interactions, Tübo $27 \%$ and Nénette $18 \%$. In contrast, Nénette was solicited in $42 \%$ of the cases, Wattana in $32 \%$ and Tübo in $26 \%$.

Food sharing involved 16 donations and 18 stealing behaviours between orangutans (table 3). Donations involved unpalatable parts (stems, petioles and wedges), whereas palatable parts (leaves) were significantly more often the object of stealing behaviours (Fisher's exact test: $\mathrm{p}<0.01$ ).

Fourteen of the 16 donations followed begging and close observations, and only 7 donations were followed by tasting by the receiver. Stealing behaviours were never followed by resistance or protest; 4 of them were followed by tasting and 9 by consumption of the plant. 
Table 3. Palatable or unpalatable parts of plants involved in donation/stealing behaviours among the 3 orangutans

\begin{tabular}{|c|c|c|c|c|c|c|c|c|c|c|}
\hline & \multicolumn{2}{|c|}{ Sage } & \multicolumn{2}{|c|}{ Ground ivy } & \multicolumn{2}{|c|}{ Balsam herb } & \multicolumn{2}{|c|}{ Hyssop } & \multicolumn{2}{|c|}{ Total } \\
\hline & Pal & Unpal & Pal & Unpal & Pal & Unpal & Pal & Unpal & Pal & Unpal \\
\hline Donation & 2 & 4 & 1 & 8 & - & 1 & - & - & 3 & 13 \\
\hline Stealing & 5 & - & 5 & 3 & 3 & 1 & 1 & - & 14 & 4 \\
\hline
\end{tabular}

Pal = Palatable parts, i.e. leaves; Unpal = unpalatable parts, i.e. stems, petioles, wedges.

Table 4. Occurrence of orangutan behaviours (taste, ingest) towards each kind of solution for first and second sessions of infusion experiment

\begin{tabular}{|c|c|c|c|c|c|c|}
\hline \multirow[t]{2}{*}{ Subjects } & \multirow[t]{2}{*}{ Plants } & \multirow[t]{2}{*}{ Solution } & \multicolumn{2}{|c|}{ First session } & \multicolumn{2}{|c|}{ Second session } \\
\hline & & & taste & ingest & taste & ingest \\
\hline \multirow[t]{6}{*}{4 orangutans pooled } & \multirow[t]{3}{*}{ p12 } & water & 0 & 3 & 1 & 3 \\
\hline & & weak infusion & 0 & 3 & 1 & 3 \\
\hline & & strong infusion & 0 & 3 & 1 & 3 \\
\hline & \multirow[t]{3}{*}{ p13 } & water & 1 & 2 & 0 & 3 \\
\hline & & weak infusion & 3 & 1 & 1 & 2 \\
\hline & & strong infusion & 1 & 3 & 0 & 3 \\
\hline \multirow[t]{6}{*}{3 orangutans pooled } & \multirow[t]{3}{*}{ p14 } & water & 2 & 1 & 1 & 1 \\
\hline & & weak infusion & 1 & 1 & 1 & 1 \\
\hline & & strong infusion & 1 & 2 & 1 & 1 \\
\hline & \multirow[t]{3}{*}{ p15 } & water & 1 & 1 & 0 & 1 \\
\hline & & weak infusion & 2 & 1 & 1 & 1 \\
\hline & & strong infusion & 1 & 1 & 2 & 1 \\
\hline
\end{tabular}

$\mathrm{p} 12$ = Marjoram; $\mathrm{p} 13$ = thyme; 14 = savory; 15 = pellitory-of-the-wall.

\section{Presentation of Infused Plants}

As with the fresh plants, the infusions were almost always tasted by the majority of individuals (table 4). The first and second presentations did not differ significantly in the proportion of orangutans ingesting infused plants (sign test: $\mathrm{n}=4, \mathrm{Z}=$ $-0.707, p=0.479$ ). No significant difference was observed between the quantity of water and of weak and strong infusions ingested during the first presentation (Kruskal-Wallis ANOVA: $\left.\mathrm{H}_{(2, \mathrm{n}=42)}=0.756, \mathrm{p}=0.685\right)$ and the second one (Kruskal-Wallis $\left.\mathrm{ANOVA}: \mathrm{H}_{(2, \mathrm{n}=42)}=0.251, \mathrm{p}=0.882\right)$.

\section{Interindividual Variability}

Significant interindividual differences in the proportion of plants consumed were observed $\left(\chi_{(3, n=49)}^{2}=12.588, p<0.01\right)$ (table 5). Considering the first sessions 
Table 5. Occurrence of ingestion of fresh and infused plants (weak and strong infusions pooled together) for each experimental condition and for each orangutan in first session

\begin{tabular}{|c|c|c|c|c|c|}
\hline & \multicolumn{2}{|c|}{ Fresh plants } & \multirow{2}{*}{$\begin{array}{l}\text { Infu- } \\
\text { sions } \\
\text { Ind }\end{array}$} & \multirow{2}{*}{$\begin{array}{l}\text { Total } \\
\text { inges- } \\
\text { tions }\end{array}$} & \multirow{2}{*}{$\begin{array}{l}\text { Neo- } \\
\text { phobia } \\
\text { rank }\end{array}$} \\
\hline & Ind & $\mathrm{Gp}$ & & & \\
\hline \multirow[t]{2}{*}{ Wattana } & $6 / 7$ & $3 / 4$ & $4 / 4$ & $13 / 15$ & \multirow[t]{2}{*}{4} \\
\hline & $100 \%$ & $75 \%$ & $100 \%$ & $87 \%$ & \\
\hline \multirow[t]{2}{*}{ Tübo } & $2 / 7$ & $2 / 4$ & $3 / 4$ & $7 / 15$ & \multirow[t]{2}{*}{3} \\
\hline & $29 \%$ & $50 \%$ & $75 \%$ & $47 \%$ & \\
\hline \multirow[t]{2}{*}{ Dayu } & $3 / 7$ & - & $2 / 4$ & $5 / 11$ & \multirow[t]{2}{*}{2} \\
\hline & $43 \%$ & & $50 \%$ & $45 \%$ & \\
\hline \multirow[t]{2}{*}{ Nénette } & $1 / 2$ & $0 / 4$ & $0 / 2$ & $1 / 8$ & \multirow[t]{2}{*}{1} \\
\hline & $50 \%$ & $0 \%$ & $0 \%$ & $13 \%$ & \\
\hline
\end{tabular}

Ind = Individual condition; $\mathrm{Gp}$ = group condition.

of presentation for fresh and infused plants together, Wattana ingested the plants in $87 \%$ of the cases and was the least cautious individual. Nénette was the most cautious, ingesting plants in only $13 \%$ of the sessions. Both males, Tübo and Dayu, ingested plants in 47 and $45 \%$ of the presentation sessions, respectively.

\section{Discussion}

Nine out of the 11 fresh plants presented to the orangutans under the combined first individual and group sessions were ingested by at least 1 individual, whereas only 2 plants were rejected by all individuals. This supports our prediction of low neophobia in weaned orangutans. In addition, the proportion of consumers did not differ significantly between the first and following sessions, suggesting that orangutans are able to quickly discern potentially edible plants. As hypothesized, to cope with the relative unpredictability of resources in the wild, orangutans may be predisposed to low cautiousness. This would allow them to make rapid use of new food items when common resources become scarce in their environment. However, comparison with other primate species is necessary to confirm the low neophobia observed as a result of the evolutionary ecology of orangutans.

Numerous close observations and food sharing between individuals occurred with all plants presented under the group condition, and all individuals were both demonstrators and observers. Differences were observed between individuals both in their degree of cautiousness and in their social interaction regarding plant consumption. The youngest female was the least cautious, the most curious and the individual least observed, whereas the oldest female was the most cautious, the least curious and observed the most by other individuals. The two males were in intermediate positions. These results emphasize the predisposition of orangutans towards social tolerance, which could facilitate social learning during the rare encounters in 
the wild. However, most of the donations, unlike the stolen items, were unpalatable plant parts. In most of the cases, they were rejected, indicating a limited role of active food transfer in plant discovery. This is confirmed by the lack of change in consumption frequency of plants initially refused.

In addition, sharing behaviours had already been observed between orangutans of this group during usual food consumption and with enrichment objects [Gustafsson, pers. obs.; Ajzenherc, pers. obs.]. These observations suggest a possible role for these interactions in usual social relationships in captivity, and that these interactions are not specifically related to novelty or feeding behaviour.

By limiting tactile, visual and olfactory cues by the use of infusions, our study indicates that without these senses, the orangutans were unable to express any preference between water and infused plants. These results and the previous literature [MacKinnon, 1974] suggest that smell could be an essential cue by which orangutans recognize edible food. Indeed the majority of fresh plants sniffed at were not ingested by orangutans. Olfaction is the first response to novel food in infant chimpanzees [Ueno and Matsuzawa, 2005], and it has been proved to be essential to obtain foodrelated information in Tonkean macaques [Chauvin and Thierry, 2005]. Among the plants not sniffed at by the orangutans were garlic mustard and bear's garlic, which have a strong garlic odour. For these last two plants, the absence of sniffing behaviours could be related to a mechanism of scent association. In fact, these captive orangutans are sometimes fed onions, which, like garlic, contain sulphurous components responsible for their specific smell. Scent association in non-human primates has already been suggested in capuchin monkeys [Baker, 1997, 2000].

To conclude, our study is the first to investigate neophobia of plants considered medicinal among orangutans. However, as suggested by other studies on primates (Saguinus fuscicollis [Menzel and Menzel, 1979]; Papio papio [Joubert and Vauclair, 1986]; Callithrix jacchus and Saguinus [Box, 1988]; Cebus apella [Glickman and Sroges, 1966; Parker, 1974; Torigoe, 1985; Visalberghi, 1988]), the captive conditions probably influenced the low neophobia and multiple interactions observed. To comprehend the influence of physiological, ecological and social factors on plant discovery, a study in semi-wild conditions and comparison with other apes would be necessary. A better understanding of the capacity of apes to acquire novel dietary habits could be of major importance for predicting the response of such endangered species to heavy deforestation of their habitat.

\section{Acknowledgments}

We are grateful to J. Rigoulet, the former director of the Ménagerie du Jardin des Plantes, for permission to conduct this study. We thank E. Joly, director of the Jardin des Plantes, and Y. Hermet for their help with plant choice. We further thank the caregivers G. Dousseau, C. Hano, S. Labbé, E. Gouverneur, H. Gauvain, S. Colomb and N. Mennecier for their help and advice throughout the study. Finally, we express our gratitude to Létitia Farris Toussaint for English language corrections, to L. Tarnaud and C.M. Hladik for their valuable comments and discussions on an earlier draft of this article, and to 3 anonymous referees for their suggestions for improving the manuscript. 


\section{References}

Addessi E, Visalberghi E (2001). Social facilitation of eating novel food in tufted capuchin monkeys (Cebus apella): input provided by group members and responses affected in the observer. Animal Cognition 4: 297-303.

Altmann J (1974). Observational study of behavior: sampling methods. Behaviour 49: 227-267.

Ames BN, Profet M, Gold LS (1990). Dietary pesticides (99.99\% all natural). Proceedings of the National Academy of Sciences of the United States of America 87: 7777-7781.

Baker M (1997). Identification and selection of fur rubbing materials by white-faced capuchin monkeys (Cebus capucinus). American Journal of Primatology 42: 93.

- Baker M (2000). Cognitive components of plant selection for fur rubbing in white-faced capuchins monkeys, Cebus capucinus. American Journal of Primatology 51: 39-50.

Barnett SA (1958). Experiments on 'neophobia' in wild and laboratory rats. British Journal of Psychology 49: 195-201.

Blackwell WH (1990). Poisonous and Medicinal Plants. Englewood Cliffs, Prentice Hall.

Box HO (1988). Behavioural responses to environmental change: observations on captive marmosets and tamarins. Animal Technology 39: 9-16.

Chauvin C, Thierry B (2005). Tonkean macaques orient their food search from olfactory cues conveyed by conspecifics. Ethology 111: 301-310.

Dominy NJ (2004). Fruits, fingers, and fermentation: the sensory cues available to foraging primates. Integrative and Comparative Biology 44: 295-303.

Dominy NJ, Lucas PW, Osorio D, Yamashita N (2001). The sensory ecology of primate food perception. Evolutionary Anthropology 10: 171-186.

Feistner ATC, McGrew WC (1989). Food sharing in primates: a critical review. In Perspectives in Primate Biology (Seth PK, Seth S, eds.), pp 21-36. New Delhi, Today and Tomorrow's.

Freeland WJ, Janzen DH (1974). Strategies in herbivory by mammals: the role of plant secondary compounds. American Naturalist 108: 269-289.

Galdikas BMF (1985). Orangutan sociality at Tanjung Puting. American Journal of Primatology 9: 101119.

Glander KE (1982). The impact of plant secondary compounds on primate feeding behavior. American Journal of Physical Anthropology 25: 1-18.

Glickman SE, Sroges RW (1966). Curiosity in zoo animals. Behaviour 26: 151-187.

Greenberg R (1990). Ecological plasticity, neophobia, and resource use in birds. Studies in Avian Biology 13: 431-437.

Heyes CM (1994). Social learning in animals: categories and mechanisms. Biological Reviews of the Cambridge Philosophical Society 69: 207-231.

Hladik CM, Simmen B (1998). Taste perception and feeding behavior in nonhuman primates and human populations. Evolutionary Anthropology 5: 58-71.

Huffman MA (1997). Current evidence for self-medication in primates: a multidisciplinary perspective. American Journal of Physical Anthropology 104: 171-200.

Huffman MA, Caton JM (2001). Self-induced increase of gut motility and the control of parasitic infections in wild chimpanzees. International Journal of Primatology 22: 329-346.

Huffman MA, Hirata S (2004). An experimental study of leaf swallowing in captive chimpanzees: insights into the origin of a self-medicative behavior and the role of social learning. Primates 45: $113-118$.

Huffman MA, Seifu M (1989). Observations on the illness and consumption of a possibly medicinal plant Vernonia amygdalina (Del.), by a wild chimpanzee in the Mahale Mountains National Park, Tanzania. Primates 30: 51-63.

Huffman MA, Paeg JE, Sukhedo MVK, Gotoh S, Kalunde MS, Chandrasiri T, Towers GHN (1996). Leafswallowing by chimpanzees: a behavioral adaptation for the control of strongyle nematode infections. International Journal of Primatology 17: 475-503.

Jaeggi AV, Dunkel LP, van Noordwijk MA, Wich SA, Sura AAL, van Schaik CP (2010). Social learning of diet and foraging skills by wild immature Bornean orangutans: implications for culture. American Journal of Primatology 72: 62-71.

Jaeggi AV, van Schaik CP, van Noordwijk MA (2008). Begging for information: mother-offspring food sharing among wild Bornean orangutans. American Journal of Primatology 70: 533-541.

Joubert A, Vauclair J (1986). Reaction to novel objects in a troop of Guinea baboons: approach and manipulation. Behaviour 96: 92-104.

Knott CD (1998). Changes in orangutan caloric intake, energy balance, and ketones in response to fluctuating fruit availability. International Journal of Primatology 19: 1061-1079. 
Krief S, Huffman MA, Sevenet T, Hladik CM, Grellier P, Loiseau PM, Wrangham RW (2006). Bioactive properties of plant species ingested by chimpanzees (Pan troglodytes schweinfurthii) in the Kibale National Park, Uganda. American Journal of Primatology 68: 51-71.

Krief S, Martin MT, Grellier P, Kasenene J, Sevenet T (2004). Novel antimalarial compounds isolated in a survey of self-medicative behavior of wild chimpanzees in Uganda. Antimicrobial Agents and Chemotherapy 48: 3196-3199.

Krief S, Thoison O, Sévenet T, Wrangham RW, Lavaud C (2005). Novel triterpenoid saponins isolated from the leaves of Albizia grandibracteata ingested by primates in Uganda. Journal of Natural Products 68: 897-903.

Laska M (2001). A comparison of food preferences and nutrient composition in captive squirrel monkeys, Saimiri sciureus, and pigtail macaques, Macaca nemestrina. Physiology and Behavior 73: 111-120.

Laska M, Freist P, Krause S (2007). Which senses play a role in nonhuman primate food selection? A comparison between squirrel monkeys and spider monkeys. American Journal of Primatology 69: 282-294.

Laska M, Salazar LTH, Luna ER (2000). Food preferences and nutrient composition in captive spider monkeys, Ateles geoffroyi. International Journal of Primatology 21: 671-683.

Leighton M (1993). Modeling dietary selectivity by Bornean orangutans: evidence for integration of multiple criteria in fruit selection. International Journal of Primatology 14: 257-313.

MacKinnon J (1974). The behaviour and ecology of wild orang-utans (Pongo pygmaeus). Animal Behaviour 22: 3-74.

Menzel EW, Menzel CR (1979). Cognitive, developmental and social aspects of responsiveness to novel objects in a family group of marmosets (Saguinus fuscicollis). Behaviour 70: 251-279.

Milton K (1993). Diet and social organization of a free ranging spider monkey population in Panama: the development of a species-typical behavior in the absence of adults. In Juvenile Primates: Life History, Development and Behaviour (Pereira ME, Fairbanks LA, eds.), pp 173-181. New York, Oxford University Press.

Morrogh-Bernard HC (2008). Fur-rubbing as a form of self-medication in Pongo pygmaeus. International Journal of Primatology 29: 1059-1064.

Parker CE (1974). Behavioral diversity in ten species of nonhuman primates. Journal of Comparative and Physiological Psychology 87: 930-937.

Rolls ET (2005). Taste, olfactory, and food texture processing in the brain, and the control of food intake. Physiology and Behavior 85: 45-56.

- Simmen B, Charlot S (2003). A comparison of taste thresholds for sweet and astringent-tasting compounds in great apes. Comptes Rendus Biologies 326: 449-455.

- Steiner JE, Glaser D, Hawilo ME, Berridge KC (2001). Comparative expression of hedonic impact: affective reactions to taste by human infants and other primates. Neuroscience and Biobehavioral Reviews 25: 53-74.

Torigoe T (1985). Comparison of object manipulation among 74 species of non-human primates. Primates 26: 182-194.

Ueno A, Matsuzawa T (2005). Response to novel food in infant chimpanzees: do infants refer to mothers before ingesting food on their own? Behavioural Processes 68: 85-90.

Visalberghi E (1988). Responsiveness to objects in two social groups of tufted capuchin monkeys (Cebus apella). American Journal of Primatology 15: 349-360.

Visalberghi E, Addessi E (2000). Seeing group members eating a familiar food enhances the acceptance of novel foods in capuchin monkeys. Animal Behaviour 60: 69-76.

Visalberghi E, Addessi E (2001). Acceptance of novel foods in capuchin monkeys: do specific social facilitation and visual stimulus enhancement play a role? Animal Behaviour 62: 567-576.

Visalberghi E, Fragaszy DM (1995). The behaviour of capuchin monkeys, Cebus apella, with novel food: the role of social context. Animal Behaviour 49: 1089-1095.

-Visalberghi E, Sabbatini G, Stammati M, Addessi E (2003). Preferences towards novel foods in Cebus apella: the role of nutrients and social influences. Physiology and Behavior 80: 341-349.

Vitale A, Queyras A (1997). The response to novel foods in common marmoset (Callithrix jacchus): the effects of different social contexts. Ethology 102: 395-403.

Wrangham RW (1995). Relationship of chimpanzee leaf-swallowing to a tapeworm infection. American Journal of Primatology 37: 297-303.

Wrangham RW, Nishida T (1983). Aspilia spp. leaves: a puzzle in the feeding behavior of wild chimpanzees. Primates 24: 276-282. 